\title{
Top Managerial Oversea Social Capital, Firm Network Position and Innovation: The Mediating Effect of Prestige and Power from Firm Network Position
}

\author{
Tian Wang \\ School of Business Administration, South China University of Technology, Guangzhou, China \\ Email: bmtw92@mail.scut.edu.cn
}

How to cite this paper: Wang, T. (2021). Top Managerial Oversea Social Capital, Firm Network Position and Innovation: The Mediating Effect of Prestige and Power from Firm Network Position. Journal of Service Science and Management, 14, 305-324.

https://doi.org/10.4236/jssm.2021.143019

Received: March 1, 2021

Accepted: June 4, 2021

Published: June 7, 2021

Copyright () 2021 by author(s) and Scientific Research Publishing Inc. This work is licensed under the Creative Commons Attribution International License (CC BY 4.0).

http://creativecommons.org/licenses/by/4.0/

\section{(c) (i) Open Access}

\begin{abstract}
In this article, we draw on the perspective of "embeddedness" with the resource dependence theory and social network theory to explore the relationship between oversea social capital, enterprise network advantageous position ("prestige" and "power") and innovation capability by employing 1533 listed companies' interlocking directorate network statistics among 2009-2013. The results show: 1) top managerial oversea social capital has a significant positive effect on enterprises' innovation capability; 2) top managerial oversea social capital has a positive effect on obtaining the enterprise network advantageous position (prestige an power); 3) enterprise network advantageous position (prestige an power) has a mediating effect on the relationship between oversea social capital and innovation capability; 4) top managerial governmental social capital has a positive moderating effect on the relationship between oversea capital and innovation capability. This research enriches researches on how does top managerial oversea social capital transfer into innovation capability, and explores the collaboration mechanism of oversea social capital and domestic governmental social capital on improving enterprises' innovation capability. This article provides both theoretical and practical implications on the future research on how to transfer top managerial oversea social capital into innovation capability improvement.
\end{abstract}

\section{Keywords}

Oversea Social Capital, Governmental Social Capital, Enterprise Innovation, Collaboration Mechanism 


\section{Introduction}

With the advent of the era of knowledge economy, innovation has become an important engine to ensure national economic growth (Lee, Ozsomer, \& Zhou, 2015), and an important source for enterprises to build competitive advantage. The key to the success of enterprise innovation in the 21st century is to establish and maintain network relationship (Kash \& Rycroft, 2002). Network relationship is an important prerequisite for enterprise innovation, and the effective exertion of network effect can promote enterprise innovation performance and growth (Cowan, Jonard, \& Zimmermann, 2007). Innovation has a high degree of uncertainty and complexity, which requires a lot of resource input and is constrained by internal resource constraints. Therefore, it is necessary to make good use of its limited internal resources and seek new ways to obtain resources. Embeddedness points out that economic behavior is embedded in social relations, so the network contains rich social capital. How to use the social capital of internal personnel and enterprises to work together on enterprise innovation ability is becoming increasingly important (Granovetter, 1985). Under the special background of the transitional economy in China, the lack of resources caused by institutional allocation makes social network an effective way for enterprises to obtain resources. The research on "social capital" from the perspective of embeddedness provides guidance for enterprises to obtain and effectively use internal and external resources.

Social capital research points out that the market does not operate in a "vacuum", and the development of enterprises depends not only on the formal system, but also on the social capital brought by the informal system (Zhao, 2003). Resources are unevenly distributed, and the construction of network relationship among enterprises is a supplement to the non-institutional factors of unevenly distributed resources under the formal system (Wang, Liu, \& Zhu, 2018). The relationship between enterprises has changed from competition to the coexistence of competition and cooperation. In order to strengthen the cooperation and resource control among enterprises, the chain director network has increasingly become one of the important channels for alliance and cooperation among enterprises (Wang, Liu, \& Zhu, 2018). Adler (2002) divides the social capital of executives into internal social capital and external social capital on the basis of literature review. Lin (2002) pointed out that social capital is a kind of resource embedded in the social structure and can be obtained or flowing through purposeful actions. Putnam (1993) introduced social capital into the field of political science, claiming that social capital belongs to the property of organizations and even the state, rather than the property of individuals, and that the research on social capital should focus on the development of organizations, rather than on the acquisition of individual development opportunities (Putnam, 1993). Therefore, this study focuses on the innovation ability of enterprises.

Considering the complexity of the external environment of enterprises, the external social capital can be further divided into overseas social capital, gov- 
ernment social capital and financial social capital based on the types of relationship objects (i.e. government, financial institutions and external companies) (Peng \& Luo, 2000). Although many scholars discuss the impact of social capital on enterprise innovation ability from the perspective of network. For example, Qian et al. (2010) pointed out that occupying the center and rich structural holes can promote the improvement of enterprise innovation performance. It is worth noting that the existing research has the phenomenon of executives' social capital replacing corporate social capital, and cannot make an in-depth study on the internal mechanism of the transformation from individual social capital to corporate social capital. In view of the limitations of the above research, this study, from the perspective of "embeddedness", uses the whole network data of chain directors of listed companies from 2009 to 2013 to study the relationship among senior executives' overseas social capital, enterprise network location and enterprise innovation ability, and tests the role of senior executives' overseas social capital in promoting enterprise network advantage, From individual social capital to enterprise innovation ability indirectly. As well as the direct effect and coordination mechanism of the transformation of executives' overseas social capital to enterprise innovation ability. For the first time, this paper makes an effective distinction between the individual level of executives' overseas social capital and the enterprise level of network location, and clarifies the dual mechanism of the transformation from executives' overseas social capital to enterprise social capital. And this research enriches researches on how does top managerial oversea social capital transfer into innovation capability, and explores the collaboration mechanism of oversea social capital and domestic governmental social capital on improving enterprises' innovation capability. This article provides both theoretical and practical implications on the future research on how to transfer top managerial oversea social capital into innovation capability improvement.

\section{Background and Theory}

\subsection{Executives Social Capital}

The concept of social capital originated from the research on the importance of founding strong families and local communities (Loury, 1976). Social capital is regarded as resources (including tangible and intangible resources) which generated from the interaction between individuals, groups or organizations (Nahapiet \& Ghoshal, 2000). Although researchers agree that social capital is coming into prominence for suppling considerable number of benefits (i.e., more career success, higher income and so on )to individuals, communities and organizations (Adler, 2002; Florin, Lubatkin, \& Schulze, 2003), they fail to come to a consensus of opinion among meanings and definitions. Bourdieu (1995) was the first person to analyze the concept of social capital in detail. In his mind, social capital is the collection of a range of resources that can be obtained from social network (Bourdieu, 1995). Coleman (2015) regards actors' social structural 
resources as social capital including physical and human capital. Various definitions of social capital could be refined into two perspectives in nature (Lin, 2002). The first perspective emphasizes that social capital is personal property from which individuals can gain benefits directly (Putnam, 1993). The other one defines social capital as the property of groups and individuals which can bring benefits for those who owned it, the group, as well as pack members (Peng \& Luo, 2000). Our research adopts the second perspective, defines social capital as the resource imbedded in the social networks which connect individuals, groups, organizations or countries, can be obtained through the network. The core issue of this idea is that network is the vital resource for individuals or organizations (i.e., gaining business information, acquire technical knowledge).

As a matter of fact, the social capital of senior executives has personal and public welfare. For the top management team, internal social capital refers to the trust, norms, common vision and other intangible resources generated by the strong relationship formed by the interaction between internal managers (Tsai \& Ghoshal, 1998), while external social capital mainly refers to the information, resources and business that enterprises can obtain from the weak relationship between the top management team and external entities (Geletkanycz \& Hambrick, 1997). The interaction between senior managers and external enterprises and organizations can effectively promote the company to obtain external information, knowledge, capital and other resources (Larson, 1992; Shu, et al., 2012). Specifically, not only can senior managers obtain personal benefits from their own social capital, but those organizations and their internal members who are not part of the social network can still obtain the resources generated in the social network by virtue of the network position of senior managers (Kostova \& Roth, 2003), for example, Senior managers can promote his or her company through their social networks to establish connections with external companies (Cai \& Sevilir, 2012). According to the top echelon theory, the values and cognition of the top management team have a significant impact on organizational performance (Hambrick \& Mason, 1984), and social capital, as an important source of resources, cannot be underestimated.

\subsection{Overseas Social Capital, Network Position and Innovation}

Drawing upon the social network theory, the companies occupying ascendant network positions have great advantage in knowledge acquisition, information collection and market opportunity identification, these external resources are able to set up the effective combination of innovation factors for companies, improve the innovation capability (Tsai, 2001). Lin (2002) also advocates that social resources embedded in the social network, such as power, wealth, and prestige, are not directly owned by individuals, but attained through social networks indirectly. Considering that the key task of senior executives is business management, their personal traits can influence strategic choices, and then affect corporate behaviors. Therefore, it can be said that the characteristics of senior 
executives can represent the enterprise's traits to a certain extent (Tsai \& Ghoshal, 1998). On this occasion, the prestige and power at the individual level could be introduced at the enterprise level, this research devotes to discuss the power and prestige that enterprises obtain in social networks based on their network position.

Drawing on the definition of prestige at the individual level, enterprise prestige refers to the degree of public recognition to the company, represents the reputation of authority. Prestige is related to social identity, which can enable the company to elicit trust in others, market opportunities, resource support, and then realize value creation. Prestige means the degree of popularity to some extent, the bigger the company's internal node degree in the social network, the higher the prestige. According to the social network theory, the centrality is the core index to measure the network position, existing relative studies mainly use this indicator to measure the prestige of a company (Larcker, So, \& Wang, 2013). Social capital theory believes that different network positions will give enterprises different advantages in controlling information and resources, thus determining the power of enterprises in social networks (Kostova \& Roth, 2003). The ability to acquire resources of enterprises depends on changing constantly the network structure to make it beneficial to themselves, continuously developing the structural holes in the network to enhance the controlling power (Putnam, 1995). It can be said that power is a structural force endowed to enterprises by the network position and is closely related to resources (Powell, 2011). Structural holes can provide information, knowledge, and other resource advantages to organizations. In previous studies, the power of enterprises in social networks is often measured by the number of structural holes (Burt, 2010).

The enterprise innovation is a complex, uncertain and dynamic process (Holmstrom, 2006), and always restrained by various factors. The company needs to cross organizational boundaries to be close to critical knowledge and resources from the social network in order to achieve innovation (Peng \& Luo, 2000). If companies have more abundant of social capital, they will be easier access to diverse information, knowledge and other resources which are the key to realizing innovation success, and then be stronger in developing and be more creative (Yli-Renko, Autio, \& Sapienza, 2001). Landry et al. (2002) pointed out that social capital is positively correlated with enterprise innovation. As the helmsman of enterprise management, the social capital of executives plays a decisive role in organizational innovation (Hambrick \& Mason, 1984). Executives with overseas background can obtain diversified information and advanced knowledge resources from their own international social network (Dai \& Liu, 2009), which can effectively identify opportunities and provide more convenient conditions for enterprise innovation. The specific analysis is as follows: first of all, senior executives with overseas experience have been embedded in the technology and market network of developed countries, which can help enterprises to participate in international scientific and technological cooperation more 
deeply, have easier access to international leading technology and technical talents, and have the ability to continuously search and obtain external advanced technology from a wider space, and introduce, master and use new technology (Saxenian, 2008). In addition, the international relationship network of executives provides rich and diverse information and knowledge resources for enterprises, which can guide the choice of enterprise innovation direction and provide reliable support for the realization of innovation. Finally, because overseas executives have a deeper understanding of technology and patent system, they pay more attention to the protection of technological innovation achievements and are more inclined to apply for technological patents for innovational achievements (Kapur \& Mchale, 2005). Above all, the study has hypothesized that:

Hypothesis 1: There is a negative relationship between TMT overseas social capital and innovation.

As going into the global era, executives with overseas experience have become the rare resources in the career market. They are people with star power who usually hold extensive knowledge, rich experience and international perspective, because of the scarcity of this type talents and their importance to the development of companies. On the one hand, executives with overseas experience provide more professional consultation and service for the company, they can promote the level of corporate governance based on the overseas work experience and professional knowledge background. According to the signal theory, it will transmit the positive information of progressing with keen determination and a spirit of uninterrupted innovations to the public when companies employ senior executives who have the global work experience, which can enhance the prestige of the enterprise (Levin, Meyer, \& Scott, 1985). On the other, executives with overseas work experience have embedded social networks at home and abroad. This means that enterprises can acquire rich and extensive social relational resources from different social networks. This enables enterprises to acquire rich and extensive social relations resources from different social networks (Gilsing et al., 2008), thus it can improve the popularity of the enterprise, and allows the company to attract a large number of external partners. Through above analysis, the paper holds the hypothesis that:

Hypothesis 2a: There is a negative relationship between TMT overseas social capital and prestige.

Enterprises can rely on their dominant position to control information, knowledge and other resources, this enables the companies to have access to power of network. Executives with the overseas background can bring the latest knowledge, advanced technology and international market information from the social network to their companies, and have close ties with different kinds of talents, for example, technical talents, management talents and so on. The enterprise can be fully supported by different resources which can strengthen the ability of creation (Burt, 2010). The resources allocation capacity enables enter- 
prises to have more voice and higher status in the social network. Furthermore, executives with overseas experience are included in different social networks simultaneously. That means the company can gain international and domestic resources, hold companies with no associated connection together and receive non-repeated and original information (Latiff \& Hassan, 2008), thus have greater power in the social network. On put together, the paper holds the hypothesis that:

Hypothesis 2b: There is a negative relationship between TMT overseas social capital and power.

With the complexity of enterprise technology innovation and uncertainty increases, relying solely on their own limited resources cannot meet the needs of enterprise technology innovation, companies have no choice but to seek external resource support and take the road of cooperative innovation (Escribano, Fosfuri, \& Tribó, 2009). The social network has a very important impact on resource acquisition and integration process. Each company occupies a different network position in a social network, different locations mean different opportunities for obtaining new knowledge and information which is the key to innovation activities (Coleman, 2000). Therefore, the network position plays an important role in the innovation of the company (Tsai, 2001). Executives with overseas working experience are embedded in social networks at home and abroad, enabling companies to acquire advanced technologies, knowledge, and other resources, and connect to different potential partners, thereby promoting companies to gain higher prestige and power. It also means that the company has an advantageous network position.

High prestige means that the company is located in a relatively central position in the social network and has a greater advantage in achieving innovation (Granovetter, 1985). Specifically, first of all, prestigious companies have access to multiple information channels and information sources, and it is easier to obtain accurate information. This allows the company created a large number of novel combinations of information to increase the possibility of achieving innovation (Dougherty \& Hardy, 1996). Second, enterprises with high prestige are more likely to acquire a wide range of new information and knowledge. This is very important for solving technological problems and overcoming technical difficulties in innovation (Ibarra, 1993). Finally, prestigious companies have strong external legitimacy, and can gather different companies relying on mutual trust, and cooperate with other innovative objects through complementing each other, risk-sharing and profit-sharing (Humphreys, Li, \& Chan, 2004). In summary, executives with overseas background also allow companies to gain high prestige and dominant network location, which contribute to achieve the optimal combination of innovation elements. Therefore, the following hypothesis is made:

Hypothesis 3a: Prestige mediates the relationship between TMT overseas social capital and innovation.

Unlike prestige, which emphasizes the direct relationship between enterprises, 
power pays more attention to the relationship pattern between enterprises. In social network, there is no direct connection among all companies. When a certain enterprise can contact with other companies with no associated connection, it means that the enterprise has hold the power by its predominant network position. The network power would be of great benefit to the realization of innovation for companies. On the one hand, the network power infers that the enterprise has the nonredundant heterogeneity connection, can acquire the differential information and knowledge, and further select and integrate those information, so as to obtain the optimal information (Mcevily \& Zaheer, 1999). On the other hand, companies with high network power can more accurately identify the qualifications of all kinds potential trading partners, distinguish development opportunities or threats more quickly, and set up the business relationship with other classic companies at low cost to achieve the innovation (Uzzi, 1997). To sum up, executives with overseas experience enables the enterprise to have higher network power, thus it is easy to establish cooperative relationship with other outstanding enterprises, thus enhance the ability of technological Innovation, so the following hypothesis is proposed:

Hypothesis 3b: Power mediates the relationship between TMT overseas social capital and innovation.

As a major player of public resources, the government controls many strategic and innovative resources. The innovative development of enterprises cannot be separated from the support of the government. In particular, under the conditions of China's transitional economy, the system is not very sound and effective, systems are lacking, institutional preferences and institutional conflicts continue to exist. The market mechanism cannot effectively play the role of resource allocation. The government needs to replace the market to allocate resources. Therefore, the government's all-embracing intervention in allocating resources has great influence on the innovation and development of enterprises, such as the strict control of key resources (such as land and finance) and administrative approval; and the implementation of a wide range of regulations on enterprises, such as Industrial policy, industry access, fiscal policy, etc. In order to obtain various scarce resources controlled by the government, the importance of forming good political and business relations between enterprises and governments is self-evident. The special stage of economic transformation makes the important role of government capital in the development of the company highlighted. It not only brings policy guidance to the company, but also enhances the company's external legitimacy, and facilitates its external financing, government subsidies, and benefits (Kapur \& Mchale, 2005).

From the above analysis, it can be seen that the senior executives' overseas social capital relies heavily on the guidance of the government in the process of promoting enterprise innovation. First of all, executives with government background can bring accurate interpretation of policy information for enterprises, and also help them quickly obtain the latest policy information (Peng \& Luo, 
2000). This can just solve the "acclimatization" dilemma of returned executives. With the escort of government capital, overseas social capital can be more smoothly transformed into enterprise innovation ability. Secondly, technological innovation has strong positive externality. Enterprises spend a lot of cost to research and develop new products and technologies, but produce less private benefits and more social benefits, and the cost cannot be fully compensated. At this time, we need the support of the government. Through institutional arrangements, we can make the social benefits generated by technological innovation of enterprises turn into private benefits as much as possible. For example, we can improve the patent protection law to protect the patented technology of enterprises, so that enterprises can safely invest as much resources as possible in innovation, so as to produce more innovative results. Thirdly, corporate executives' government social capital enables enterprises to connect to more external advantageous resources through the government (Zeng, Lv, \& Liu, 2016). It is worth pointing out that due to the dominant position of the government in the allocation of social resources, the resources connected by the government are high-quality and reliable, which makes the enterprises further enhance the ability to obtain advantageous resources at low cost on the basis of their overseas social capital, and thus play a role of resource support in the formation of enterprise innovation ability. Finally, the injection of government social capital by senior executives brings more mobile information about technological innovation to enterprises ( $\mathrm{He} \& \mathrm{He}, 2016$ ), which can better guide overseas social capital to improve enterprise innovation ability. On the basis of the analysis above, the research made the following hypothesis:

Hypothesis 4: TMT government social capital negatively moderates the relationship between TMT overseas social capital and innovation.

To sum up, the conceptual model of this paper is showing in Figure 1.

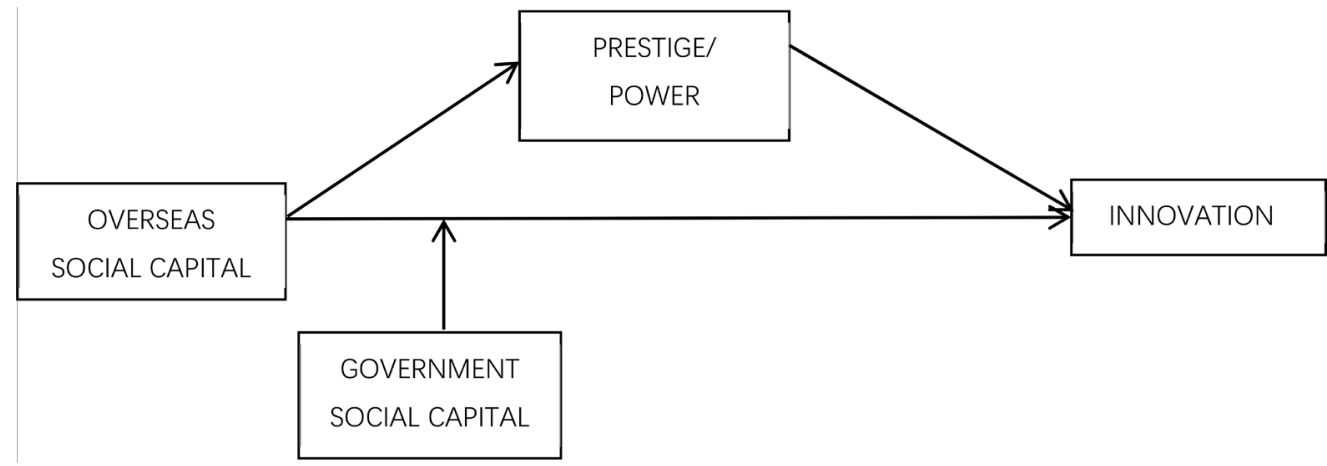

Figure 1. Theory framework.

\section{Research Design}

\subsection{Data and Sample}

Interlocking directorates refers to a director who serves on the board of two or more companies at the same time, they can bring connections between different 
firms and represents the social capital of the enterprise (Mizruchi \& Stearns, 1988). Companies can acquire diverse resources from the relational network formed by interlocking directorates, especially knowledge resources that is key to innovation (Wincent, Anokhin, \& örtqvist, 2010). Based on this, this paper uses the interlocking directorates to build a network of listed companies, explore the impact of executives' social capital on corporate innovation through this network.

Considering the availability of data, this paper pays close attention to Chinese A-share listed companies. The data used in this article are all from the CSMAR database and company annual reports. In addition, the following samples were deleted for the reliability of the research results through consulting the annual reports and the other related information of the listed companies: ST, SST and ${ }^{*}$ ST listed companies, and other samples with the serious data loss. In order to ensure the completeness of the relational network, all the listed companies after the elimination are included in the study. Finally, the whole network of the listed company's chain directors is constructed based on the 5608 unbalanced panel data of 1533 companies which covered the period from 2009 to 2013 in China. The specific information for the variables is shown in Table 1.

Table 1. Main variables.

\begin{tabular}{|c|c|c|c|}
\hline Variables & Symbols & $\begin{array}{l}\text { Full name of } \\
\text { variables }\end{array}$ & The definition of variables \\
\hline \multirow{2}{*}{$\begin{array}{l}\text { Dependent } \\
\text { variable }\end{array}$} & INNO_T & Innovation & Natural logarithm of total number of patents at the end of year $t+2$ \\
\hline & INNO_TR & Innovation & $\begin{array}{l}\text { Natural logarithm of total number of patents pro ratio at the end of year } t+2 \\
\text { (Robust test) }\end{array}$ \\
\hline $\begin{array}{l}\text { Independent } \\
\text { variable }\end{array}$ & OVERSEA_M & $\begin{array}{l}\text { Mean overseas social } \\
\text { capital }\end{array}$ & $\begin{array}{l}\text { Mean number of people in executive team who have oversea working experiences } \\
\text { at year } t\end{array}$ \\
\hline \multirow{2}{*}{ Mediate variable } & PRESTIGE & Prestige in network & The degree centrality of the listed firm's whole network at the end of year $t+1$ \\
\hline & POWER & Power in network & The effect size in the listed firm's whole network at the end of year $t+1$ \\
\hline \multirow{2}{*}{$\begin{array}{l}\text { Moderate } \\
\text { variable }\end{array}$} & GOVENMENT_M_N & $\begin{array}{l}\text { Mean government } \\
\text { social capital }\end{array}$ & $\begin{array}{l}\text { Mean number of people in executive team who have national government } \\
\text { working experiences at year } t\end{array}$ \\
\hline & GOVENMENT_M_P & $\begin{array}{l}\text { Mean government } \\
\text { social capital }\end{array}$ & $\begin{array}{l}\text { Mean number of people in executive team who have provincial government } \\
\text { working experiences at year } t \text { (Robust test) }\end{array}$ \\
\hline \multirow{7}{*}{ Control variable } & SCALE & Scale of the enterprise & Natural logarithm of the number of the employees at the end of year $t$ \\
\hline & AGE & Age of the enterprise & Length of time from the founding year to the year $t$ \\
\hline & SOE & $\begin{array}{l}\text { Nature of actual } \\
\text { controller }\end{array}$ & $\begin{array}{l}\text { Dumb variable, the variable values } 1 \text { when the actual controller is state-owned } \\
\text { enterprises, otherwise the variable values } 0\end{array}$ \\
\hline & DUAL & Dual & $\begin{array}{l}\text { Dumb variable, the variable values } 1 \text { when a person is both the chairman of the } \\
\text { board and the general manager at the end of year } t \text {, otherwise values } 0\end{array}$ \\
\hline & BOARD & Board Scale & Board scale of the enterprise at the end of year $t$ \\
\hline & IND & Industry & Dumb variable, set up to refer to 2001 SFC industry classification. \\
\hline & YEAR & Year & The year that the data was collected \\
\hline
\end{tabular}




\subsection{Variables}

Innovation. In consideration of the availability of the data and agreement of statistical caliber, this research measure the innovation ability of companies by means of the number of patents based on the achieved results of previous research. Innovation ability index computed as follows: the number of patents of invention, the number of patent for utility models, and the number of appearance design calculate the weighted average according to $0.5,0.3$, and 0.2 respectively, then make a log transformation and get the target value. The study also uses natural logarithm of total number of patents pro ratio to conduct a robustness test.

Prestige. On the foundation of absorbing the study accomplishment before, the study adopts degree prestige as the measurement of a company's prestige. The degree prestige focuses on the number of companies that are directly linked to a specific company in the social network ( $\mathrm{Ma} \& \mathrm{Li}, 2011$ ). This study used the UCINET6.0 software to measure the prestige of the company, the formula for calculation is as follows:

$$
\text { PRESTER }=\sum_{i=1}^{n} a\left(p_{i}, p_{k}\right) .
$$

Power. Unlike prestige which emphasizes the direct connection between enterprises, the power is focused on the linking role of the enterprise in the social network. When it is located at "structural hole" in comparatively loose social networks, the certain company can obtain more social capitals, and gain the control power that derived from the dependence of other companies on its functions as a bridge (Burt, 2010). This research used the UCINET6.0 software to measure the number of "structural hole" of the certain company, using the quantitative index to denote the power of an enterprise. The calculation is shown below:

$$
\text { POWER }=\sum_{j}\left(1-\sum_{q} p_{i q} m_{j q}\right), q \neq i, j .
$$

Social capital. In this paper, the number of senior executives with government background is used as the measurement of government social capital. The study also use mean number of people in executive team who have provincial government working experiences at year $t$ to conduct a robustness test.

Control variables. Based on previous research, controls variables include R\&D, company size, corporate age, ownership, board scale in this article. In addition, in order to ensure the validity and consistency of model estimation, the research winsorizes the continuous variables measure at the upper and lower $1 \%$ tails of the distribution before the regression analysis. In order to verify the causal relationship between the various variables and assure the stability of results, this study assumes the independent variable, the moderate variable and the control variables at a certain year $t$, affect the mediate variables at the year $t+1$, both independent variable and mediate variables trigger innovation of the year $t$ 
+2 . The specific information for the variables is shown in Table 1 .

\section{Results}

Table 2 presents the descriptive statistics for variables. Table $3 \&$ Table 4 report the results of hierarchical multiple regressions. We add the controlled variables ( $R \& D$ investment for avoiding the impact of funds on Innovation, ownership for eliminating enterprise-level influence, enterprise size, age, board scale, the industry and data years) into the regression analysis. All variables in the regression model are shown in Table 3. Results from test for multi-collinearity show that the VIFs (variance inflation factors) of all variables are lower than 6 which is lower than the alert limit (VIF $=10)$.

Table 2. The result of correlation analysis.

\begin{tabular}{cccccc}
\hline \multicolumn{5}{c}{ INNO_T } & OVERSEA_T GOVENMENT_T_G \\
\hline INNO_T & 1 & & & & \\
OVERSEA_T & $0.159^{* * *}$ & 1 & & & \\
GOVENMENT_T_P & $0.174^{* * *}$ & $0.192^{* * *}$ & 1 & & \\
PRESTIGE & $0.096^{* * *}$ & $0.157^{* * *}$ & $0.121^{* * *}$ & 1 & \\
POWER & $0.122^{* * *}$ & $0.180^{* * *}$ & $0.137^{* * *}$ & $0.952^{* * *}$ & 1 \\
MEAN & 257.488 & 4.468 & 1.050 & 3.125 & 2.633 \\
SD & 1.000 & 4.000 & 0.000 & 1.000 & 1.000 \\
\hline
\end{tabular}

The second column M1 in Table 3 report the results for regressions relating overseas social capital and innovation (Hypotheses 1). Before we turn to a discussion of the coefficients of independent and dependent variables related to the presented hypotheses, we controlled variables of $R \& D$ investment, enterprise size, and age, board scale, ownership, industry and year. We found the impact of overseas social capital on innovation is positive $(\beta=2.771, P<0.05)$. Hypothesis 1 is supported by data validation. Table 4 shows the robust test by changing the dependent variables by using natural logarithm of total number of patents pro ratio. The conclusion is the same as the former. The third column M2 and the seventh column M6 in Table 3 report the results for regressions relating overseas social capital and prestige (Hypotheses 2a), and power (Hypotheses $2 \mathrm{~b}$ ). Results show that overseas social capital is positively associated with prestige ( $\beta$ $=0.029, P<0.05)$ and power $(\beta=0.022, P<0.05)$ which support Hypothesis2a and Hypotheses $2 \mathrm{~b}$.

The forth column M3 and the eighth column M7 in Table 3 demonstrate the mediating role of prestige and power between overseas social capital and innovation. The commonly-used method of testing meditation is from Baron and Kenny (1986)'s study. The variable plays the mediating role when a combination of the following conditions is true: 1) Changes in independent variables can significantly explain changes in dependent variables; 2) The change of independent 
Table 3. Mean overseas social capital, network position and innovation output.

\begin{tabular}{|c|c|c|c|c|c|c|c|}
\hline & $\begin{array}{c}\text { M1 } \\
\text { INNO_T }\end{array}$ & $\begin{array}{c}\text { M2 } \\
\text { PRESTIGE }\end{array}$ & $\begin{array}{c}\text { M3 } \\
\text { INNO_T }\end{array}$ & $\begin{array}{c}\text { M4 } \\
\text { INNO_T }\end{array}$ & $\begin{array}{c}\text { M5 } \\
\text { INNO_T }\end{array}$ & $\begin{array}{c}\text { M6 } \\
\text { POWER }\end{array}$ & $\begin{array}{c}\text { M7 } \\
\text { INNO_T }\end{array}$ \\
\hline \multirow[t]{2}{*}{ OVERSEA_T } & $2.771^{* *}$ & $0.029^{* *}$ & $2.656^{\star *}$ & 1.855 & 1.774 & $0.022^{\star *}$ & $2.621^{\star *}$ \\
\hline & -2.13 & -2.32 & -2.04 & -1.46 & -1.39 & -2.16 & -2.01 \\
\hline \multirow[t]{2}{*}{ PRESTIGE } & & & $3.975^{\star * \star}$ & & $3.271^{\star *}$ & & \\
\hline & & & -3.1 & & -2.57 & & \\
\hline \multirow[t]{2}{*}{ POWER } & & & & & & & $6.687^{\star * *}$ \\
\hline & & & & & & & -4.34 \\
\hline \multirow[t]{2}{*}{ GOVENMENT_T_P } & & & & $22.926^{\star \star *}$ & $22.282^{\star * *}$ & & \\
\hline & & & & -6.46 & -6.22 & & \\
\hline \multirow[t]{2}{*}{$\begin{array}{c}\text { OVERSEA_T }{ }^{*} \\
\text { GOVENMENT_T_P }\end{array}$} & & & & $4.538^{\star * *}$ & $4.515^{\star * *}$ & & \\
\hline & & & & -3.4 & -3.37 & & \\
\hline \multirow[t]{2}{*}{ SOE } & $-87.956^{* * *}$ & $-0.640^{\star \star}$ & $-85.414^{\star \star \star}$ & $-83.028^{\star \star \star}$ & $-80.955^{\star * *}$ & -0.255 & $-86.253^{\star * *}$ \\
\hline & -3.96 & -2.36 & -3.84 & -3.86 & -3.76 & -1.11 & -3.89 \\
\hline \multirow[t]{2}{*}{ SCALE } & $87.428^{\star * \star}$ & $0.293^{\star * *}$ & $86.265^{\star * *}$ & $81.771^{\star \star \star}$ & $80.920^{\star * *}$ & $0.274^{\star * \star}$ & $85.597^{\star * \star}$ \\
\hline & -16.46 & -7.1 & -16.36 & -15.7 & -15.66 & -7.91 & -16.35 \\
\hline \multirow[t]{2}{*}{ AGE } & $-1.425^{\star *}$ & -0.005 & $-1.406^{* *}$ & -0.69 & -0.685 & -0.003 & $-1.408^{* *}$ \\
\hline & -2.03 & -0.56 & -2.01 & -1.00 & -0.99 & -0.35 & -2.02 \\
\hline \multirow[t]{2}{*}{ DUAL } & $40.362^{\star * \star}$ & -0.029 & $40.478^{\star * *}$ & $35.439^{* * *}$ & $35.610^{* * *}$ & 0.014 & $40.269^{\star * *}$ \\
\hline & -5.64 & -0.31 & -5.65 & -4.97 & -4.99 & -0.18 & -5.64 \\
\hline \multirow[t]{2}{*}{ BOARD } & 2.253 & $0.262^{\star * *}$ & 1.212 & -0.717 & -1.519 & $0.270^{\star * *}$ & 0.444 \\
\hline & -0.73 & -8.09 & -0.4 & -0.24 & -0.53 & -10.01 & -0.15 \\
\hline YEAR & $\mathrm{Y}$ & $\mathrm{Y}$ & $\mathrm{Y}$ & $\mathrm{Y}$ & $\mathrm{Y}$ & $\mathrm{Y}$ & $\mathrm{Y}$ \\
\hline INDU & $\mathrm{Y}$ & $\mathrm{Y}$ & $\mathrm{Y}$ & $\mathrm{Y}$ & $\mathrm{Y}$ & Y & $\mathrm{Y}$ \\
\hline \multirow[t]{2}{*}{ CONS } & $-698.862^{* * *}$ & 0.018 & $-698.936^{* * *}$ & $-657.901^{\star * *}$ & $-658.490^{\star * *}$ & $-1.528^{* * *}$ & $-688.642^{* * *}$ \\
\hline & -13.77 & -0.04 & -13.83 & -13.72 & -13.76 & -3.67 & -13.85 \\
\hline $\mathrm{N}$ & 5608 & 5608 & 5608 & 5608 & 5608 & 5608 & 5608 \\
\hline $\mathrm{R} 2$ & 0.201 & 0.06 & 0.203 & 0.221 & 0.222 & 0.078 & 0.205 \\
\hline $\mathrm{F}$ & 15.643 & 11.546 & 15.235 & 15.226 & 14.872 & 14.099 & 15.248 \\
\hline
\end{tabular}

variables can explain the change of mediating variables; 3) the impact of independent variables on dependent variables should be insignificant or weaker when the mediator is controlled, and at the same time the mediator affects the dependent variables. Results show that prestige $(\beta=3.975, P<0.01)$ and power $(\beta=6.687, P<0.01)$ are positively associated with innovation. Besides, when prestige and power are added to the regression model, the relationship between overseas social capital and innovation is weakened $(\beta=2.656, P<0.05$, when it comes to prestige; $\beta=2.621, P<0.05$, when it comes to power), but still signifi- 
cant. which suggests partial mediation. Through the analysis, prestige and power partially mediates the effects of overseas social capital on innovation, Hypothesis $3 \mathrm{a}$ and Hypotheses $3 \mathrm{~b}$ are supported. Table 4 shows the robust test by changing the dependent variables by using natural logarithm of total number of patents pro ratio. The conclusion is the same as the former.

To assess the first-stage moderated mediation, the following conditions were tested 1) overseas social capital has significant impacts on innovation; 2) prestige and power have effects on innovation; 3 ) overseas social capital and government

Table 4. Mean overseas social capital, network position and innovation output (robust test).

\begin{tabular}{|c|c|c|c|c|c|c|c|}
\hline & $\begin{array}{c}\text { M1' } \\
\text { INNO_TR }\end{array}$ & $\begin{array}{c}\text { M2' } \\
\text { PRESTIGE }\end{array}$ & $\begin{array}{c}\text { M3' } \\
\text { INNO_TR }\end{array}$ & $\begin{array}{c}\text { M4' } \\
\text { INNO_TR }\end{array}$ & $\begin{array}{c}\text { M5' } \\
\text { INNO_TR }\end{array}$ & $\begin{array}{c}\text { M6' } \\
\text { POWER }\end{array}$ & $\begin{array}{c}\text { M7' } \\
\text { INNO_TR }\end{array}$ \\
\hline \multirow[t]{2}{*}{ OVERSEA_T } & $0.981^{* *}$ & $0.029^{* *}$ & $0.945^{\star *}$ & 0.601 & 0.569 & $0.022^{\star *}$ & $0.934^{\star *}$ \\
\hline & -2.43 & -2.32 & -2.33 & -1.58 & -1.5 & -2.16 & -2.31 \\
\hline \multirow[t]{2}{*}{ PRESTIGE } & & & $1.266^{* * *}$ & & $1.154^{\star * \star}$ & & \\
\hline & & & -3.21 & & -2.95 & & \\
\hline \multirow[t]{2}{*}{ POWER } & & & & & & & $2.123^{\star * *}$ \\
\hline & & & & & & & -4.48 \\
\hline \multirow[t]{2}{*}{ GOVENMENT_S_N } & & & & $15.045^{\star * *}$ & $14.638^{* * *}$ & & \\
\hline & & & & -6.08 & -5.87 & & \\
\hline \multirow{2}{*}{$\begin{array}{c}\text { OVERSEA_T }{ }^{*} \\
\text { GOVENMENT_S_N }\end{array}$} & & & & $2.483^{\star \star *}$ & $2.513^{\star * *}$ & & \\
\hline & & & & -2.86 & -2.89 & & \\
\hline \multirow[t]{2}{*}{ SOE } & $-25.498^{\star \star \star}$ & $-0.640^{* *}$ & $-24.688^{\star \star \star}$ & $-21.881^{\star \star \star}$ & $-21.138^{\star \star \star}$ & -0.255 & $-24.957^{\star * *}$ \\
\hline & -3.60 & -2.36 & -3.48 & -3.19 & -3.08 & -1.11 & -3.53 \\
\hline \multirow[t]{2}{*}{ SCALE } & $27.430^{\star \star \star}$ & $0.293^{\star * *}$ & $27.059^{\star \star \star}$ & $25.565^{\star \star \star}$ & $25.254^{\star \star \star}$ & $0.274^{\star * *}$ & $26.848^{\star \star \star}$ \\
\hline & -16.6 & -7.1 & -16.48 & -15.99 & -15.9 & -7.91 & -16.47 \\
\hline \multirow[t]{2}{*}{ AGE } & $-0.483^{\star *}$ & -0.005 & $-0.477^{\star *}$ & -0.283 & -0.279 & -0.003 & $-0.478^{\star *}$ \\
\hline & -2.22 & -0.56 & -2.19 & -1.31 & -1.29 & -0.35 & -2.20 \\
\hline \multirow[t]{2}{*}{ DUAL } & $11.743^{* * *}$ & -0.029 & $11.780^{\star * \star}$ & $9.969^{* * *}$ & $10.002^{\star * *}$ & 0.014 & $11.714^{\star * *}$ \\
\hline & -5.34 & -0.31 & -5.36 & -4.53 & -4.54 & -0.18 & -5.35 \\
\hline \multirow[t]{2}{*}{ BOARD } & 0.641 & $0.262^{\star * *}$ & 0.31 & 0.019 & -0.275 & $0.270^{* * *}$ & 0.067 \\
\hline & -0.67 & -8.09 & -0.33 & -0.02 & -0.31 & -10.01 & -0.07 \\
\hline YEAR & $\mathrm{Y}$ & $\mathrm{Y}$ & $\mathrm{Y}$ & $\mathrm{Y}$ & Y & $\mathrm{Y}$ & Y \\
\hline INDU & Y & $\mathrm{Y}$ & $\mathrm{Y}$ & $\mathrm{Y}$ & $\mathrm{Y}$ & $\mathrm{Y}$ & $\mathrm{Y}$ \\
\hline \multirow[t]{2}{*}{ CONS } & $-220.545^{\star * *}$ & 0.018 & $-220.568^{\star * \star}$ & $-207.466^{* * *}$ & $-207.538^{\star * \star}$ & $-1.528^{* * *}$ & $-217.299^{* * *}$ \\
\hline & -14.01 & -0.04 & -14.06 & -14.24 & -14.29 & -3.67 & -14.08 \\
\hline $\mathrm{N}$ & 5608 & 5608 & 5608 & 5608 & 5608 & 5608 & 5608 \\
\hline $\mathrm{R} 2$ & 0.205 & 0.06 & 0.207 & 0.224 & 0.226 & 0.078 & 0.209 \\
\hline $\mathrm{F}$ & 15.78 & 11.546 & 15.349 & 15.144 & 14.771 & 14.099 & 15.377 \\
\hline
\end{tabular}


social capital have the significant interactive effect on both prestige and power, this is, the relationship between overseas social capital and prestige, and power will change with the different level of government social capital. The last condition is the key to verify the first-stage moderated mediation, when the moderating variable is higher or lower, the mediating effect will increase or weaken.

The sixth column M5 in Table 3 state that government social capital moderates the relationship between overseas social capital and innovation $(\beta=4.538$, $\mathrm{P}<0.01)$, such that overseas social capital is more positively associated with innovation when government social capital is high rather than low. Thus, there was support for Hypothesis 4 . Table 4 shows the robust test by changing the moderating variables by using mean number of people in executive team who have provincial government working experiences at year $t$. The conclusion is the same as the former.

\section{Discussion}

For enterprises, innovation is an important source of core competitive advantage. How to obtain external information and resources in time, so as to enhance the innovation ability of enterprises, is a major problem faced by enterprises. Based on the whole network data of 1533 listed companies from 2009 to 2013, this paper empirically tests the relationship between executives' overseas social capital, executives' government social capital, network location (reputation and power) and enterprise innovation, which provides a new perspective for the research of enterprise innovation ability, The conclusions are as follows: 1) the overseas social capital of executives can enhance the innovation ability of enterprises; 2) Senior executives' overseas social capital and senior executives' government social capital play a synergistic role, and they are the key factors to promote the innovation ability of enterprises; 3) Senior executives' overseas social capital, by optimizing the network position (reputation and power) of enterprises to enhance the innovation ability of enterprises, is one of the key ways to explain how to improve the innovation ability of enterprises.

\subsection{Theoretical and Practical Implications}

Based on the social network theory and resource dependence theory, this study clarifies the mechanism of executive social capital on enterprise innovation capability, and makes the following three theoretical contributions: firstly, this study puts forward the direct and indirect paths for overseas social capital to enhance enterprise innovation capability, Previous studies only explored the impact of directors' overseas background on innovation performance from the surface, but did not know its internal mechanism. This study just makes up for this defect. Under the background of global competition, many enterprises have been competing for high-level talents with overseas background. This is mainly because the survival and development of enterprises need the help of high-tech and top-notch talents from overseas. Specifically, the world-class professional 
knowledge and open and inclusive management concept can directly enhance the innovation ability of enterprises. In addition, a wide range of international interpersonal network provides a congenital condition for enterprises to obtain advantageous network position, which indirectly promotes the improvement of innovation ability. On the one hand, hiring overseas talents to convey the signal of open innovation and forge ahead to the outside world, so as to enhance the popularity of enterprises, attract more external resources, and promote the improvement of enterprise innovation ability, On the other hand, overseas connectivity improves the power of enterprises in overseas networks and improves the control ability of enterprises over overseas information and resources, which makes it easier for enterprises to obtain the scarce resources needed for enterprise innovation. Secondly, from different network perspectives, this study verifies and develops that the enterprises occupying the dominant position will have higher enterprise innovation ability. The reason is that the network position with high centrality and rich structural holes has more advantages in acquiring heterogeneous knowledge, information and resources, which is the unity of advantageous network position and advantageous information resources, Only in this way can we hold the view that occupying a favorable network position is helpful to improve the innovation ability of enterprises. Finally, the synergy of multiple social networks. Previous studies have shown that executive social capital in a single social network has a positive role in promoting enterprise innovation, but few studies focus on the impact of the synergy of executive social capital in multiple networks on enterprise innovation ability.

Based on the research conclusions, this paper puts forward the following three practical suggestions: 1) attach importance to the enterprise and external connection. In the uncertain external environment, maintaining the innovation ability of enterprises puts forward higher requirements for the external openness of enterprises. Enterprise innovation highly depends on external information, knowledge and resources. Therefore, enterprises should pay attention to hiring talents with external background. Especially with the increasingly fierce global competition, enterprises can consider increasing the proportion of returned talents to ensure that enterprises have international innovation ability and competitiveness; 2) Focus on optimizing their position in multiple networks. Advantageous network position often represents advantageous resources, information and knowledge, which play a decisive role in the promotion of enterprise innovation ability. Therefore, enterprises should pay attention to their "reputation" and "power" in multiple social networks, and improve their ability to control resources and information in multiple networks; 3) Attach importance to the relationship with the government. In the multiple social networks, the connection network between enterprises and government is the most special, especially in the period of China's transition economy, the government's intervention in resource allocation has a great impact on enterprises. Therefore, enterprises should fully understand the government's policies and obtain responsive re- 
sources under the guidance of the government in order to truly enhance the innovation ability of enterprises.

\subsection{Limitations and Future Research Directions}

Although this paper tries to improve the research design as far as possible, there are still the following deficiencies: on the one hand, the study of social network in this study stops at the discussion of senior management's government social network and senior management's overseas social network. It is worth noting that the multiple networks of enterprises also include strategic alliance network, innovation network, etc., which can be further expanded in the future. On the other hand, considering the availability and importance of data, this study only measures the social capital of executives, but ignores other individuals except executives. The follow-up study can further expand the scope of data collection to compare and supplement the impact of different individual social capital on enterprise innovation ability.

\section{Conflicts of Interest}

The author declares no conflicts of interest regarding the publication of this paper.

\section{References}

Adler, P. S. (2002). Social Capital: Prospects for a New Concept. Academy of Management Review, 27, 17-40. https://doi.org/10.5465/amr.2002.5922314

Baron, R. M., \& Kenny, D. A. (1986). The Moderator-Mediator Variable Distinction in Social Psychological Research: Conceptual, Strategic, and Statistical Considerations. Journal of Personality and Social Psychology, 51, 1173. https://doi.org/10.1037/0022-3514.51.6.1173

Bourdieu, P. (1995). Sociology in Question. Anthropological Quarterly, 68, 67. https://doi.org/10.2307/3317467

Burt, R. S. (2010). Structural Holes: The Social Structure of Competition (pp. 7060-7066). Cambridge, MA: Harvard University Press.

Cai, Y., \& Sevilir, M. (2012). Board Connections and M\&A Transactions. Journal of Financial Economics, 103, 327-349. https://doi.org/10.1016/j.jfineco.2011.05.017

Coleman, J. S. (2000). Chapter 2 Social Capital in the Creation of Human Capital. In Knowledge \& Social Capital (pp. 17-41). Amsterdam: Elsevier. https://doi.org/10.1016/B978-0-7506-7222-1.50005-2

Coleman, J. S. (2015). Social Capital in the Creation of Human Capital. American Journal of Sociology, 94, 95-120. https://doi.org/10.1086/228943

Cowan, R., Jonard, N., \& Zimmermann, J. B. (2007). Bilateral Collaboration and the Emergence of Innovation Networks. Management Science, 53, 1051-1067. https://doi.org/10.1287/mnsc.1060.0618

Dai, O., \& Liu, X. (2009). Returnee Entrepreneurs and Firm Performance in Chinese High-Technology Industries. International Business Review, 18, 373-386. https://doi.org/10.1016/j.ibusrev.2009.03.004

Dougherty, D., \& Hardy, C. (1996). Sustained Product Innovation in Large, Mature Or- 
ganizations: Overcoming Innovation-to-Organization Problems. Academy of Management Journal, 39, 1120-1153. https://doi.org/10.2307/256994

Escribano, A., Fosfuri, A., \& Tribó, J. A. (2009). Managing External Knowledge Flows: The Moderating Role of Absorptive Capacity. Research Policy, 38, 96-105.

https://doi.org/10.1016/j.respol.2008.10.022

Florin, J., Lubatkin, M., \& Schulze, W. (2003). A Social Capital Model of High-Growth Ventures. Academy of Management Journal, 46, 374-384. https://doi.org/10.2307/30040630

Geletkanycz, M. A., \& Hambrick, D. C. (1997). The External Ties of Top Executives: Implications for Strategic Choice and Performance. Administrative Science Quarterly, 42, 654-681. https://doi.org/10.2307/2393653

Gilsing, V., Nooteboom, B., Vanhaverbeke, W. et al. (2008). Network Embeddedness and the Exploration of Novel Technologies: Technological Distance, Betweenness Centrality and Density. Research Policy, 37, 1717-1731. https://doi.org/10.1016/j.respol.2008.08.010

Granovetter, M. (1985). Economic Action and Social Structure: The Problem of Embeddedness. American Journal of Sociology, 91, 481-510. https://doi.org/10.1086/228311

Hambrick, D. C., \& Mason, P. A. (1984). Upper Echelons: The Organization as a Reflection of Its Top Managers. Academy of Management Review, 9, 193-206. https://doi.org/10.5465/amr.1984.4277628

He, X., \& He, Y. (2016). Research on Mediating Effect of Government-Industry-Academy Cooperation between Social Capital and Innovation. Science \& Technology Progress \& Policy, 33, 11-15.

Humphreys, P. K., Li, W. L., \& Chan, L. Y. (2004). The Impact of Supplier Development on Buyer-Supplier Performance. Omega, 32, 131-143. https://doi.org/10.1016/j.omega.2003.09.016

Ibarra, H. (1993). Network Centrality, Power, and Innovation Involvement: Determinants of Technical and Administrative Roles. Academy of Management Journal, 36, 471-501. https://doi.org/10.2307/256589

Kapur, D., \& Mchale, D. (2005). The Global Migration of Talent: What Does It Mean for Developing Countries? Washington DC: Center for Global Development.

Kash, D. E., \& Rycroft, R. (2002). Emerging Patterns of Complex Technological Innovation. Technological Forecasting \& Social Change, 69, 581-606. https://doi.org/10.1016/S0040-1625(01)00171-8

Kostova, T., \& Roth, K. (2003). Social Capital in Multinational Corporations and a Micro-Macro Model of Its Formation. Academy of Management Review, 28, 297-317. https://doi.org/10.5465/amr.2003.9416356

Landry, R., Amara, N., \& Lamari, M. (2002). Does Social Capital Determine Innovation? To What Extent? Technological Forecasting \& Social Change, 69, 681-701. https://doi.org/10.1016/S0040-1625(01)00170-6

Larcker, D. F., So, E. C., \& Wang, C. C. Y. (2013). Boardroom Centrality and Firm Performance. Journal of Accounting \& Economics, 55, 225-250.

https://doi.org/10.1016/j.jacceco.2013.01.006

Larson, A. (1992). Network Dyads in Entrepreneurial Settings: A Study of the Governance of Exchange Relationships. Administrative Science Quarterly, 37, 76-104. https://doi.org/10.2307/2393534

Latiff, H. S. B. H., \& Hassan, A. (2008). Rise and Fall of Knowledge Power: An In-Depth Investigation. Humanomics the International Journal of Systems \& Ethics, 24, 17-27. 
https://doi.org/10.1108/08288660810851441

Lee, R. P., Ozsomer, A., \& Zhou, K. Z. (2015). Introduction to the Special Issue on "Innovation in and from Emerging Economies". Industrial Marketing Management, 50, 16-17. https://doi.org/10.1016/j.indmarman.2015.07.005

Levin, H., Meyer, J. W., \& Scott, W. R. (1985). Organizational Environments: Ritual and Rationality. Administrative Science Quarterly, 3, 295-296.

Lin, N. (2002). Social Capital: A Theory of Social Structure and Action. Cambridge: Cambridge University Press. https://doi.org/10.1017/CBO9780511815447

Loury, G. C. (1976). A Dynamic Theory of Racial Income Differences. Discussion Papers.

Mcevily, B., \& Zaheer, A. (1999). Bridging Ties: A Source of Firm Heterogeneity in Competitive Capabilities. Strategic Management Journal, 20, 1133-1156. https://doi.org/10.1002/(SICI)1097-0266(199912)20:12<1133::AID-SMJ74>3.0.CO;2-7

Mizruchi, M. S., \& Stearns, L. B. (1988). A Longitudinal Study of the Formation of Interlocking Directorates. Administrative Science Quarterly, 33, 194-210. https://doi.org/10.2307/2393055

Nahapiet, J., \& Ghoshal, S. (2000). Social Capital, Intellectual Capital, and the Organizational Advantage. Academy of Management Review, 23, 119-157. https://doi.org/10.1016/B978-0-7506-7222-1.50009-X

Peng, M. W., \& Luo, Y. (2000). Managerial Ties and Firm Performance in a Transition Economy: The Nature of a Micro-Macro Link. Academy of Management Journal, 43, 486-501. https://doi.org/10.2307/1556406

Powell, W. W. (2011). Network Dynamics and Field Evolution. American Journal of Sociology, 110, 1132-1205. https://doi.org/10.1086/421508

Putnam, R. (1993). The Prosperous Community: Social Capital and Public Life. American Prospect, 13, 35-42.

Putnam, R. (1995). Bowling Alone, America's Declining of Social Capital. Journal of Democracy, 6, 65-78. https://doi.org/10.1353/jod.1995.0002

Qian, X. H., Xu, W. L., \& Yang, Y. F. (2010). Firm Network Position, Indirect Ties, and Innovative Performance. China Industrial Economics, No. 2, 78-88.

Saxenian, A. L. (2008). The New Argonauts: Regional Advantage in a Global Economy. Economic Geography, 84, 105-108. https://doi.org/10.1111/j.1944-8287.2008.tb00393.x

Shu, C., Page, A. L., Gao, S. et al. (2012). Managerial Ties and Firm Innovation: Is Knowledge Creation a Missing Link? Journal of Product Innovation Management, 29, 125-143. https://doi.org/10.1111/j.1540-5885.2011.00883.x

Tsai, W. (2001). Knowledge Transfer in Intraorganizational Networks: Effects of Network Position and Absorptive Capacity on Business Unit Innovation and Performance. Academy of Management Journal, 44, 996-1004. https://doi.org/10.2307/3069443

Tsai, W., \& Ghoshal, S. (1998). Social Capital and Value Creation: The Role of Intrafirm Networks. Academy of Management Journal, 41, 464-476. https://doi.org/10.2307/257085

Uzzi, B. (1997). Social Structure and Competition in Interfirm Networks: The Paradox of Embeddedness. Administrative Science Quarterly, 42, 35-67. https://doi.org/10.2307/2393808

Wang, Z., Liu, Y. L., \& Zhu, L. (2018). Research on the Relationship between Industry Connection and Corporate Competitiveness from the Perspective of "Embeddedness"-The Mediating Effect of "Prestige" and "Power". East China Economic Management, No. 1, 127-136.

Wincent, J., Anokhin, S., \& örtqvist, D. (2010). Does Network Board Capital Matter? A 
Study of Innovative Performance in Strategic SME Networks. Journal of Business Research, 63, 265-275. https://doi.org/10.1016/j.jbusres.2009.03.012

Yli-Renko, H., Autio, E., \& Sapienza, H. J. (2001). Social Capital, Knowledge Acquisition, and Knowledge Exploitation in Young Technology-Based Firms. Strategic Management Journal, 22, 587-613. https://doi.org/10.1002/smj.183

Zeng, P., Lv, D., \& Liu, Y. (2016). Technological Innovation, Political Connections and Government Innovation Support: A Mechanism and Path. Science Research Management, 37, 17-26.

Zhao, Y. D. (2003). New Development of Social Capital Theory. Social Sciences Abroad, No. 3, 54-59. 